\title{
Urinary tract infection caused by a small colony variant form of capnophilic Escherichia coli leading to misidentification and non-reactions in antimicrobial susceptibility tests
}

\author{
Yu Jin Park', Nguyen Le Phuong ${ }^{1}$, Naina Adren Pinto ${ }^{1}$, Mi Jeong Kwon ${ }^{1}$, Roshan D'Souza ${ }^{1,2}$, Jung-Hyun Byun ${ }^{1 *}$, \\ Heungsup Sung ${ }^{3}$ and Dongeun Yong
}

\begin{abstract}
Background: Small colony and capnophilic variant cases have been separately reported, but there has been no reports of their simultaneous presence in one isolate. We report a case of Escherichia coli with coexpressed small colony and capnophilic phenotypes causing misidentification in automated biochemical kits and non-reactions in antimicrobial susceptibility test cards.

Case presentation: An 86-year-old woman developed urinary tract infection from a strain of Escherichia coli with $\mathrm{SCV}$ and capnophilic phenotypes in co-existence. This strain did not grow without the presence of $\mathrm{CO}_{2}$, and therefore proper identification from automated system was not possible. $16 \mathrm{~s}$ rRNA sequencing and matrix-assisted laser desorption/ionization time-of-flight mass spectrometry was able to identify the bacteria.
\end{abstract}

Conclusion: As these strains do not grow on culture parameters defined by CLSI or on automated systems, proper identification using alternative methods are necessary.

Keywords: Small colony variant, Capnophilic, Escherichia coli, Misidentification

\section{Background}

Small colony variants (SCV) can be defined as a naturally occurring sub-population of bacteria characterized by their reduced colony size and distinct biochemical properties [1]. Capnophilic E. coli, which thrive in the presence of high concentrations of carbon dioxide, have rarely been reported [2,3]. SCV and capnophilic variant cases have never been reported in co-existence. Herein, we report the first case of E. coli with coexpressed SCV and capnophilic phenotypes isolated from a urinary tract infection.

* Correspondence: jhbyun@yuhs.ac; JHBYUN@yuhs.ac

'Department of Laboratory Medicine and Research Institute of Bacterial Resistance, Severance Hospital, Yonsei University College of Medicine, 50-1 Yonsei-ro, Seodaemun-gu, Seoul 03722, Republic of Korea

Full list of author information is available at the end of the article

\section{Case report}

An 86-year-old woman visited our hospital with foamy urine and foul odor. Urinalysis showed many WBCs $(163.7 \mathrm{WBCs} / \mu \mathrm{L})$ and bacteria $(11,343.7$ bacteria/uL), and positivity for nitrite. Gram-negative coccobacilli were revealed upon microscopic examination. The sample was cultured on sheep blood agar plate (BAP) and MacConkey agar plates at $35^{\circ} \mathrm{C}$ in a $5 \% \mathrm{CO}_{2}$ atmosphere for $24 \mathrm{~h}$. After one day of incubation, $>100,000 \mathrm{CFU} / \mathrm{ml}$ of pinpoint Gramnegative colonies grew on the BAP with $10,000 \mathrm{CFU} / \mathrm{ml}$ of Gram-positive cocci. After isolation of pinpoint colonies and another 24-h incubation, the pinpoint Gram-negative colonies were irregularly divided into large colonies and pinpoint SCV colonies on BAP (Table 1).

While the VITEK 2 system (bioMerieux, Durham, USA) identified the pinpoint colony as Burkholderia cepacia group, the Bruker Biotyper (Bruker Daltonics, Leipzig,

(c) The Author(s). 2018 Open Access This article is distributed under the terms of the Creative Commons Attribution 4.0 International License (http://creativecommons.org/licenses/by/4.0/), which permits unrestricted use, distribution, and reproduction in any medium, provided you give appropriate credit to the original author(s) and the source, provide a link to the Creative Commons license, and indicate if changes were made. The Creative Commons Public Domain Dedication waiver (http://creativecommons.org/publicdomain/zero/1.0/) applies to the data made available in this article, unless otherwise stated. 
Table 1 Bacterial identification and antimicrobial susceptibility testing results

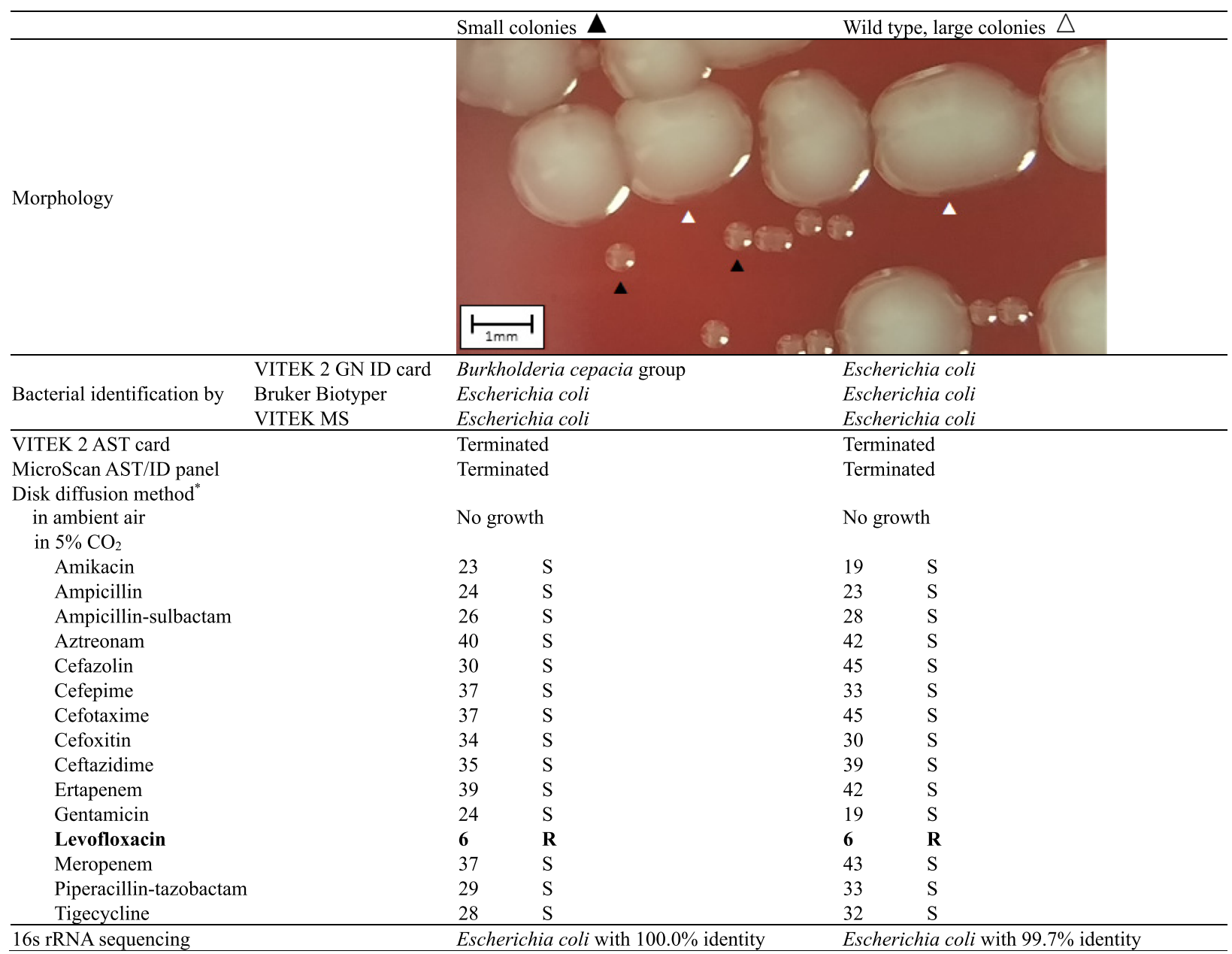

*Disk diffusion method results are given as measured zone diameters [8] and interpretive category. $S$ susceptible, $R$ resistant

Germany) and VITEK MS (bioMerieux, Marcy-l'Étoile, France) matrix-assisted laser desorption/ionization time-of-flight mass spectrometry (MALDI-TOF MS) systems identified both colonies as E. coli. The $16 \mathrm{~s}$ rRNA sequencing concluded both isolates were E. coli. As automated systems in an ambient air were unable to grow capnophilic SCVs, antimicrobial susceptibility testing profile was determined through disk diffusion method [4]. With the exception of levofloxacin resistance, bacteria was susceptible to all other antimicrobials. From these findings, we concluded that this isolate was $\mathrm{CO}_{2}$-dependent and had the ability to revert to its natural large form in the presence of $\mathrm{CO}_{2}$.

Whole genome sequencing analysis by the MiSeq ${ }^{\circ}$ system (Illumina, San Diego, USA) was performed to inspect assumed genes that contained previously-reported causative mutations for the E. coli SCV phenotype (hemB, menC, and $\operatorname{lip} A$ gene) $[1,5]$, but no genetic mutational variations were observed between the two strains. The yadF gene was not present in either strain, which is consistent with previous reports about capnophilic E. coli strains [6].

\section{Discussion}

The first E. coli SCV was reported in 1931, but there have been only few reports from clinical specimens [7-9]. Interestingly, this SCV strain was also capnophilic. The bacterial growth for reported capnophilic E. coli strains formed either large colonies in the presence of $\mathrm{CO}_{2}$ or no colonies in the absence of $\mathrm{CO}_{2}[2,3]$. To the best of our knowledge, this is the first report of $E$. coli with coexpressed SCV and capnophilic phenotype. Fortunately, this strain was susceptible to all other antimicrobials with the exception of levofloxacin, and therefore did not cause any severe outcome clinically. However, if this strain was to acquire drug resistance in the future, it is diagnostically crucial not 
to misidentify or neglect such strain for proper therapeutic purposes.

Additional criteria including $\mathrm{CO}_{2}$ conditions are needed because CLSI guidelines defining incubation conditions for Enterobacteriaceae involve $35^{\circ} \mathrm{C}$ ambient air [4], which are unsuitable for growing capnophilic SCVs. We advise that all urine cultures should be incubated in an environment containing $5 \% \mathrm{CO}_{2}$ to avoid overlooking of such strains. Proper identification using alternative methods such as MALDI-TOF MS systems are necessary for these capnophilic strains.

\section{Abbreviations}

BAP: Blood agar plate; MALDI-TOF MS: Matrix-assisted laser desorption/ ionization time-of-flight mass spectrometry; SCV: Small colony variants

\section{Acknowledgements}

Not applicable.

\section{Funding}

None received.

\section{Availability of data and materials}

Not applicable to this article as no datasets were generated or analyzed.

\section{Authors' contributions}

The study was planned and designed by YP, NP, NAP, MK, RD, JB, HS, and DY. MK collected the samples. YP, JB, HS, and DY conducted the experiments. The interpretation of the genetic results was done by NP, NAP, and RD. The manuscript was prepared by YP and JB. All authors contributed to and commented on the manuscript. All authors read and approved the final manuscript.

\section{Ethics approval and conesnt to participate}

The study was approved by the Institutional Review Board of Yonsei University Severance Hospital, Seoul, Korea (\#2018-1951-001).

\section{Consent for publication}

Not applicable.

\section{Competing interests}

The authors declare that they have no competing interests.

\section{Publisher's Note}

Springer Nature remains neutral with regard to jurisdictional claims in published maps and institutional affiliations.

\section{Author details \\ ${ }^{1}$ Department of Laboratory Medicine and Research Institute of Bacterial Resistance, Severance Hospital, Yonsei University College of Medicine, 50-1 Yonsei-ro, Seodaemun-gu, Seoul 03722, Republic of Korea. ${ }^{2}$ J.Craig Venter Institute (JCVI), 9605 Medical Center Dr \#150, Rockville, MD 20850, USA. ${ }^{3}$ Department of Laboratory Medicine, Asan Medical Center, University of Ulsan College of Medicine, 88 Olympic-ro 43-gil, Songpa-gu, Seoul 05505, Republic of Korea.}

Received: 3 September 2018 Accepted: 12 November 2018 Published online: 20 November 2018

\section{References}

1. Santos V, Hirshfield I. The physiological and molecular characterization of a small colony variant of Escherichia coli and its phenotypic rescue. PLoS One. 2016. https://doi.org/10.1371/journal.pone.0157578.

2. Lu W, Chang K, Deng S, Li M, Wang J, Xia J, et al. Isolation of a capnophilic Escherichia coli strain from an empyemic patient. Diagn Microbiol Infect Dis. 2012. https://doi.org/10.1016/j.diagmicrobio.2012.03.020.
3. Tena D, González-Praetorius A, Sáez-Nieto JA, Valdezate S, Bisquert J. Urinary tract infection caused by capnophilic Escherichia coli. Emerg Infect Dis. 2008. https://doi.org/10.3201/eid1407.071053.

4. Clinical and Laboratory Standards Institute. Performance standards for antimicrobial susceptibility testing. 28th edition ed. In: CLSI document M100: clinical and laboratory standards institute; 2018.

5. Tashiro Y, Eida H, Ishii S, Futamata H, Okabe S. Generation of small colony variants in biofilms by Escherichia coli harboring a conjugative F plasmid. Microbes Environ. 2017. https://doi.org/10.1264/jsme2.ME16121.

6. Sahuquillo-Arce JM, Chouman-Arcas R, Molina-Moreno JM, Hernandez-Cabezas A, Frasquet-Artes J, Lopez-Hontangas JL. Capnophilic Enterobacteriaceae. Diagn Microbiol Infect Dis. 2017. https://doi.org/10.1016/j.diagmicrobio.2017.01.010.

7. Roggenkamp A, Sing A, Hornef M, Brunner U, Autenrieth IB, Heesemann J. Chronic prosthetic hip infection caused by a small-colony variant of Escherichia coli. J Clin Microbiol. 1998:36(9):2530-4.

8. Sendi P, Frei R, Maurer TB, Trampuz A, Zimmerli W, Graber P. Escherichia coli variants in periprosthetic joint infection: diagnostic challenges with sessile bacteria and sonication. J Clin Microbiol. 2010. https://doi.org/10.1128/jcm. 01562-09.

9. Tappe D, Claus H, Kern J, Marzinzig A, Frosch M, Abele-Horn M. First case of febrile bacteremia due to a wild type and small-colony variant of Escherichia coli. Eur J Clin Microbiol Infect Dis. 2006. https://doi.org/10.1007/ s10096-005-0072-0.

\section{Ready to submit your research? Choose BMC and benefit from:}

- fast, convenient online submission

- thorough peer review by experienced researchers in your field

- rapid publication on acceptance

- support for research data, including large and complex data types

- gold Open Access which fosters wider collaboration and increased citations

- maximum visibility for your research: over $100 \mathrm{M}$ website views per year

At BMC, research is always in progress.

Learn more biomedcentral.com/submissions 